\title{
EI and WLB Effects in Performance of Women Employees in IT Companies at Chennai
}

\author{
M. Theboral Victoriya, R. Angayarkanni
}

\begin{abstract}
Emotional Intelligence is a lot of delicate aptitudes or else the bury and intra-individual abilities of a person which thinks about one's feelings, oversee feelings, inspires one, perceive feelings in others, and to deal with the connections.. Emotional intelligence assumes an imperative job in improving the exhibition of an individual and an Organization. Work Life Balance is a provocative subject for IT officials and has likewise esplanade the specialists to do investigate in this theme. This study was led to discover the effect of Emotional Intelligence and Work life Balance on Organizational Performance with Special reference to ladies IT representatives in Chennai. Survey was conducted among 386 women IT representatives working in the IT organizations of Chennai. In this descriptive research, the convenience sampling method was used. The analysis was done by SPSS 21.0. Statistical tests such as One Way ANOVA, Chi Square Test, Correlation and Regression analysis are incorporated. The discoveries uncovered that there is a noteworthy effect of enthusiastic knowledge and work life balance on Organizational Performance of ladies IT experts in Chennai.
\end{abstract}

Keywords : Work life balance, Work stress, Work issues, individual causes, Emotional intelligence, etc.

\section{INTRODUCTION}

Emotional Intelligence (EI) is defined as the skill to recommends that emotional intelligence can be educated and reinforced, some others states that it is a natural characteristic feature of an individual. The increased growth and change made Indian women to enter into the IT jobs. Balancing the Emotions and work \& life is an important concept in the dual earning family.

Emotional Intelligence helps the staff to extend their knowingness, expression, creativity, tolerance, trust and integrity and improves relation within the organization that paves manner for the rise within the performance of every worker and also the organization. This article focuses on the contact of Emotional Intelligence and Work life Balance on Organisational Performance with Special relevance ladies IT staff in Chennai.

Revised Manuscript Received on December 05, 2019.

* Correspondence Author

M. Theboral Victoriya*, Ph.D. Research Scholar, Assistant Professor in Commerce, Prince Shri Venkateshwara Arts \& Science College, Chennai, Tamil Nadu, India.

Dr. R. Angayarkanni, Associate Professor \& Research Supervisor, Department of Commerce, Faculty of Humanities and Science, SRM Institute of Science and Technology, Kattankulathur, Tamil Nadu, India. observe, govern, and appraise feelings. Some analysis earlier

\section{REVIEW OF LITERATURE}

Goleman (1998) found that Emotional Intelligence is the quality whish separate successful executives from unsuccessful executives who are having poorer emotional control. Carmeli (2003) identified that senior managers having highly emotional intelligent can handle work family conflict in a careful manner than the low emotional intelligent managers. Vittal (2003) pointed out that the failure rates of women in their job gets increased due to their marriage and childbirth because childcare and housework remains as women's tasks whatever may be her income, educational level and employment. Today's Organisations face lot of external obstacles in its way as competition through technological, ethical, political changes, and liberalisation, privatisation and globalisation, this can be strategically handled only through its internal positive and satisfied human resources (Avgar et al., 2011; Singh and Kassa, 2016). Most of the organisations rely heavily on their competent human resources to achieve their objectives with strategic proposition (Dessler, 2014; Kaliannan et al., 2016).

Sharma et al (2016) noted in his research that work life balance initiatives uphold the employee satisfaction when they experiencing hard working conditions in the organisation. Research by Goodwin and Richards (2017) shows that when the employees are not supported with work life balance drive by their organisation tend to leave their organisations.

\section{RESEARCH OBJECTIVES}

1. To observe relation between emotional intelligence and Work life balance of women IT workers in Chennai with reverence to Demographic and Work factors.

2. To discover the part of emotional intelligence and Work life balance on Organisational Performance of women IT employees in Chennai

3. To discover the relationships among Demographic influences such as Age, Qualification, Marital status, Number of Children, Income and the Number of dependants with the Emotional Intelligence of IT women employees with respect to Chennai.

4. To determine the relationships among work influences such as Skill and Work experience, Emotional stability, Motivation, Management Support, Work environment, Training and Development, Team support with the Organisational

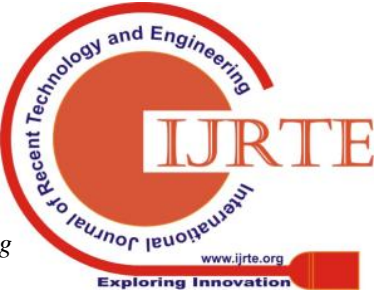




\section{EI and WLB Effects in Performance of Women Employees in IT Companies at Chennai}

performance of IT women employees with reference to Chennai.

\section{HYPOTHESIS OF THE STUDY}

The subsequent are the hypothesis framed for this research.

Null Hypothesis 1: Demographic factors have no influence on Age, Qualification, and Marital status, Number of Children, Income and the Number of dependants with the Emotional Intelligence of IT women employees with respect to Chennai.

Null Hypothesis 2: Work factors have no influence on Employees Skill and Work experience, Emotional stability, Motivation, Management Support, Work environment, Training and Development, Team support with the organisational performance of IT women employees with respect to Chennai.

Null Hypothesis 3: Emotional intelligence \& Work life balance have no influence on Organisational Performance of women IT employees in Chennai.

\section{RESEARCH METHODOLOGY}

In this descriptive research, the convenience sampling method was used. The Survey was conducted among 386 IT women employees working in the IT companies of Chennai. The analysis was done by SPSS 17.0. Statistical tests such as One Way Anova, Chi Square Test, Correlation and
Regression analysis was used to test the Influence of Emotional Intelligence and Work life Balance on Organisational Performance and how the Demographic influences such as Age, Qualification, Marital status, Sum of Children, Income and the Sum of dependants of the respondents are having an impact with the Emotional Intelligence and the work factors such as Employees Skill and Work experience, Emotional stability, Motivation, Management Support, Work environment, Training and Development, Team support are having an impact with the organisational performance of IT women employees with respect to Chennai.

\section{RESULTS AND DISCUSSION}

\section{A. Reliability test}

Table 6.1 Reliability Statistics

\begin{tabular}{|c|c|}
\hline \multicolumn{2}{|c|}{ Reliability Statistics } \\
\hline Cronbach's Alpha & Number of Items \\
\hline 0.88 & 20 \\
\hline
\end{tabular}

The reliability test was conducted and the Cronbach's Alpha value is 0.88 , which proves that the collected data was consistent. Using Likerts scale 20 Questions were framed which is used as the questionnaires.

Table 6.2 Demographic factors on Emotional Intelligence tested using One Way Anova

\begin{tabular}{|c|c|c|c|c|c|c|}
\hline Factors & Details & Frequency & Mean Value & $\mathbf{F}$ & $\mathbf{P}$ & Result \\
\hline \multirow{3}{*}{ Age } & Less than 30 Years & 140 & 2.134 & \multirow{3}{*}{5.162} & \multirow{3}{*}{$0.003 * *$} & \multirow{3}{*}{ Significant } \\
\hline & 21-40Years & 136 & 2.256 & & & \\
\hline & Above 40 Years & 110 & 2.547 & & & \\
\hline \multirow{2}{*}{ Qualification } & Under Graduate & 175 & 2.358 & \multirow[t]{2}{*}{0.374} & \multirow{2}{*}{$0.585 * *$} & \multirow{2}{*}{ Not Significant } \\
\hline & Post Graduate & 211 & 2.342 & & & \\
\hline \multirow{2}{*}{ Marital status } & Married & 186 & 2.307 & \multirow{2}{*}{0.764} & \multirow{2}{*}{$0.645^{*}$} & \multirow{2}{*}{ Not Significant } \\
\hline & Unmarried & 200 & 2.304 & & & \\
\hline \multirow{2}{*}{ Number of Children } & Single Child & 272 & 2.473 & \multirow{2}{*}{3.876} & \multirow{2}{*}{$0.63 * *$} & \multirow{2}{*}{ Not Significant } \\
\hline & 2 and More children & 114 & 2.142 & & & \\
\hline \multirow{2}{*}{ Income } & Less than 5 Lakhs per annum & 276 & 2.765 & \multirow{2}{*}{4.864} & \multirow{2}{*}{$0.002 * *$} & \multirow{2}{*}{ Significant } \\
\hline & Above 5 Lakhs per annum & 110 & 2.466 & & & \\
\hline \multirow{2}{*}{ Number of dependants } & Up to 2 members & 151 & 2.347 & \multirow{2}{*}{0.351} & \multirow{2}{*}{$0.843 * *$} & \multirow{2}{*}{ Not Significant } \\
\hline & More than 2 members & 235 & 2.332 & & & \\
\hline
\end{tabular}

Source: Primary Data

Inference:

For this study, 386 women IT Workers selected from different IT firms all over Chennai. How the Demographic influences such as Age, Qualification, and Marital status, Number of Children, Income and the Number of dependants of the respondents have impact with the Emotional Intelligence was tested using One Way Anova and it is found that, among the demographic factors age and Income are significant. There is an influence between the age and Income level with emotional Intelligence and proved that Emotional Intelligence of the IT women employees differ on the basis of Age and Income. The remaining demographic influences such as Qualification, Marital status, Number of Children and the Number of dependants were not having the significant difference which shows that the Emotional Intelligence of the IT women employees will not differ on the source of Qualification, Marital status, Number of Children and the Number of dependants. Above 40 Years of Age are having High Emotional Intelligence based on the mean value 2.547. While compared with the Income of the respondents Less than 5 Lakhs per annum income employees are having higher emotional intelligence based on the mean value 2.765. 
Table 6.3 Influence of the work issues on the organisational performance verified by Chi square test

\begin{tabular}{|l|c|}
\hline \multicolumn{1}{|c|}{ Work issues } & Level of Significance \\
\hline Employees Skill and Work experience & $0.000 * *$ \\
\hline Emotional stability & $0.000 * *$ \\
\hline Motivation & $0.002 * *$ \\
\hline Management Support & $0.000 * *$ \\
\hline Work environment & $0.000 * *$ \\
\hline Training and Development & $0.002 * *$ \\
\hline Team support & $0.001 * *$ \\
\hline Source: Primary Data ** significant by $5 \%$ & \\
\hline
\end{tabular}

\section{Inference:}

The relations between the work factors such as Employees Skill and Work experience, Emotional stability, Motivation, Management Support, Work environment, Training and Development, Team support on the organisational performance were tested using Chi square test. The standards are noteworthy with all the effort issues then henceforth reject the null hypothesis and verified that there is a substantial association among the work factors of the IT women employees of Chennai on the organisational performance of IT women employees with reverence to Chennai. All the Work aspects are having an impact on organisational Performance.

Table 6.4 showing relationship between the emotional intelligence \& Work life balance on Organisational Performance of women IT employees in Chennai verified by Regression analysis

Table 6.4 i) Descriptive statistics of the Emotional intelligence \& Work life balance on Organisational

Performance of women IT employees in Chennai

\begin{tabular}{|c|l|c|c|c|}
\hline \multirow{2}{*}{ S.N } & \multicolumn{4}{|c|}{ Descriptive Statistics } \\
\cline { 2 - 5 } & & Mean & $\begin{array}{c}\text { Std. } \\
\text { Deviation }\end{array}$ & $\mathrm{N}$ \\
\hline 1. & $\begin{array}{l}\text { Emotional intelligence \& Work life } \\
\text { balance }\end{array}$ & 8.34 & 1.652 & 386 \\
\hline 2. & Organisational Performance & 6.753 & .342 & 386 \\
\hline
\end{tabular}

Table 6.4 ii) the associations of the Emotional intelligence \& Work life balance on Organisational Performance of women IT employees in Chennai

\begin{tabular}{|c|c|c|c|c|}
\hline \multirow{2}{*}{ S.N } & \multicolumn{4}{|c|}{ Correlations } \\
\hline & & & $\begin{array}{l}\text { Emotional intelligence \& } \\
\text { Work life balance }\end{array}$ & Organisational Performance \\
\hline \multirow{2}{*}{1.} & \multirow{2}{*}{$\begin{array}{c}\text { Pearson } \\
\text { Correlation }\end{array}$} & Emotional intelligence \& Work life balance & 1.000 & 0.875 \\
\hline & & Organisational Performance & 0.875 & 1.000 \\
\hline \multirow{2}{*}{2.} & \multirow{2}{*}{ Sig. (1-tailed) } & Emotional intelligence \& Work life balance & . & .002 \\
\hline & & Organisational Performance & .002 & . \\
\hline \multirow{2}{*}{3.} & \multirow{2}{*}{$\mathrm{N}$} & Emotional intelligence \& Work life balance & 386 & 386 \\
\hline & & Organisational Performance & 386 & 386 \\
\hline
\end{tabular}

Table 6.4 iii) Regression Value of the Emotional intelligence \& Work life balance on Organisational Performance of women IT employees in Chennai

\begin{tabular}{|c|c|c|c|}
\hline Regression & $\mathbf{R}^{\mathbf{2}}$ & Adj R $^{\mathbf{2}}$ & Standard Error of the Estimate \\
\hline $.804 \mathrm{a}$ & .653 & .652 & 0.48651 \\
\hline
\end{tabular}

Table 6.4 iv) Analysis of variance of the Emotional intelligence \& Work life balance on Organisational Performance of women IT employees in Chennai.

\begin{tabular}{|c|c|c|c|c|c|}
\hline \multicolumn{2}{|c|}{ Model } & Sum of squares & $\begin{array}{c}\text { Degrees of } \\
\text { freedom }\end{array}$ & Mean Sum Square & Sig. \\
\hline \multirow{3}{*}{1} & Regression & 164.341 & 1 & 164.341 & 0.246 \\
\cline { 2 - 6 } & Residual & 96.171 & 385 & 387.043 \\
\cline { 2 - 5 } & Total & 260.512 & 386 & \\
\hline
\end{tabular}

Source: Computed Data

a. Predictors: (Constant), Emotional intelligence \& Work life balance

b. Dependent Variable: Organisational Performance 
Table 6.4 v) Showing the Coefficients of the Emotional intelligence \& Work life balance on Organisational Performance of women IT employees in Chennai.

\begin{tabular}{|c|c|c|c|c|c|c|}
\hline \multicolumn{7}{|c|}{ Coefficientsa } \\
\hline & \multirow{2}{*}{ Model } & \multicolumn{2}{|c|}{ Unstandardized Coefficients } & \multirow{2}{*}{$\begin{array}{c}\text { Standardized Coefficients } \\
\text { Beta }\end{array}$} & \multirow{2}{*}{$\mathrm{T}$ value } & \multirow{2}{*}{$\begin{array}{c}\text { Significan } \\
\text { ce }\end{array}$} \\
\hline & & B & Standard Error & & & \\
\hline \multirow{2}{*}{1} & (Constant) & 0.342 & .086 & & 4.247 & .000 \\
\hline & Emotional intelligence \& Work life balance & 0.876 & .022 & 0.861 & 27.243 & .000 \\
\hline
\end{tabular}

a. Dependent Variable: Organisational Performance

\section{Interpretation}

The table $6.4 \mathrm{i}-\mathrm{v})$ depicts that Emotional intelligence \& Work life balance which are independent variable, and the dependent variable such as Organisational Performance among IT women employees in Chennai. The collected data were tested using the t-test multiple regressive model. The results depict that the Emotional intelligence \& Work life balance has significant effect in Organisational Performance. Complete multiple regression models taking Organisational Performance as a dependent variable came out to be substantial. As depicted, the coefficient of determination came out to be .653 which means this model has explanatory power of $65.3 \%$ with respect to Emotional intelligence \& Work life balance. The minimum variance or $\mathrm{F}$ ratio (687.043) came out to be significant at $1 \%$. The situation remained initiated to a positive substantial impression of these independent variables on the dependent variable $(F=687.043)(0.000)$. The values of Beta Factors for all the independent variables show a confident suggestion inside the model. The value of $(\mathrm{R}$. Square $=.653)$ and $(\mathrm{R}=.804)$ predict a goodness of fit between the set of independent variable Emotional intelligence \& Work life balance and the dependent variable Organisational Performance. When we examine the regression analysis value, Significant value obtained is 0.000 which is smaller than the $\mathrm{P}$ value $(\mathrm{P}<0.01)$ and hence the null hypothesis there is no significant relationship between the Emotional intelligence \& Work life balance on the Organisational Performance gets rejected at $1 \%$ significance level and proved that, Emotional intelligence \& Work life balance have an impact on the Organisational Performance in respect of IT women employees in Chennai.

\section{CONCLUSION}

In this inspection was focussed to determine the Influence of Emotional Intelligence and Work life Balance on Organizational Performance with Special reference to Women IT representatives in Chennai. The Cronbach's Alpha value obtained was 0.88 , which proves that the collected data was consistent. Among the statistic variables age and Income are huge. There is a noteworthy distinction between the age and Income with the passionate Intelligence and demonstrated that Emotional Intelligence of the IT ladies representatives vary based on Age and Income. The staying statistic factors, for example, Qualification, Marital status, Number of Children and the Number of dependants were not having the huge contrast which demonstrates that

the Emotional Intelligence of the IT ladies workers won't vary based on Qualification, Marital status, Number of Children and the Number of dependants. Over 40 Years of Age are having High Emotional Intelligence dependent on the mean worth 2.547. While contrasted and the Income of the respondents Less than 5 Lakhs for each annum salary representatives are having higher passionate insight dependent on the mean worth 2.765. The work factors, for example, Employees Skill and Work involvement, Emotional soundness, Motivation, Management Support, Work condition, Training and Development, Team backing are affecting authoritative Performance. It is proved that Emotional insight and Work life equalization affect the Organizational Performance among IT women representatives in Chennai.

\section{REFERENCES}

1. Carmeli, A. (2003). The relationship between emotional intelligence and work attitudes, behavior and outcomes. Journal of managerial psychology, 18, pp 788-813.

2. Akintayo, D. I. (2010). Work-family conflict and organization commitment among industrial workers in Nigeria. Journal of Psychology and counselling, 2(1), pp1-8.

3. Fisher, K., and Layte, R. (2004). Measuring work-life balance using time diary data electronic International Journal of Time Use Research, 1(1), pp $1-13$.

4. Goleman, D. (1995). Emotional intelligence, New York: Bantam Books.

5. Vittal (2003). Strategies to empower women in the IT sector" In: The International Conference on Women in the digital era: opportunities and challenges, December, pp 10-12, Annamalai University, India.

6. www.asianjournal.com.
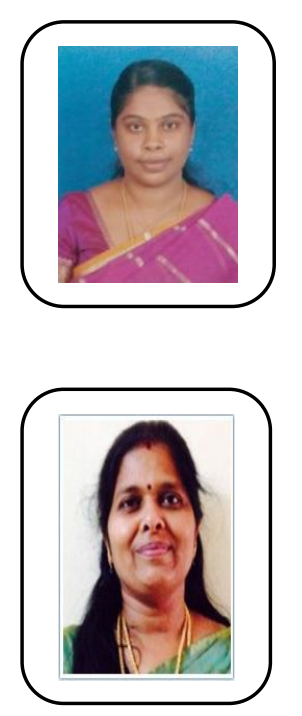

\section{AUTHORS PROFILE}

Mrs.M.Theboral Victoriya, M.Com, M.Phil ,pursuing Doctorate in Human Resource Management at SRM Institute of Science and Technology. She has completed under graduate ,M.com and M.Phil in Bharathiar University.She has published Five research articles in various national and international journals.

Dr. R. Angayarkanni, holds a Doctorate in Human resource management. She has completed under graduate in University of Madras, M.com in University of Madras, MBA in Periyar University and M.Phil in Bharathiar University. She is currently Associate Professor in SRM Institute of Science and Technology. 